raturhistorisk værk, hvis fortsættelse det bliver spændende at følge. Det store tekstmateriale rummer såvel ny viden om som nye fortolkninger af kvinders skrift og tale, og har stor historisk værdi som udtryk for kvinders tanker, erfaringer og livsomstændigheder. Hvad læseren undervejs kan savne er en større diskussion af, hvordan disse tekster er interessante som litteratur? En mere markant udfoldelse af dette spørgsmål måtte i højere grad gå i clinch med den mandlige litterære kanons kriterier, der hidtil har frasorteret mange af de kvindelige forfattere. Endvidere kunne det føre til en større refleksion over, hvad der sker ikke blot med litteraturhistorien, men også med måderne at læse og vurdere litteratur på, når kvindelige forfatterskaber sættes i fokus?

\section{Karin Højersholt}

Anders Østergaard (red.): Skud-tekstanalysen i dag, Kbh. 1992.

I kritikerantologien Skud - tekstanalysen $i$ dag præsenteres fem fortolkninger af den samme fiktionstekst: J.P. Jacobsens: »Et Skud i Taagen «. Seks kritikere har - med varierende grad af kaldsfølelse - indvilliget $i$ at optræde som eksponenter for fem aktuelle tekstteoretiske positioner, der hver især fremstilles og diskuteres udførligt i sammenhæng med demonstrationen af deres respektive tekstanalytiske konsekvenser. Erik A. Nielsen forfægter et hermaneutisk-eksistentielt litteratursyn, mens Søren Schou forsvarer den socialhistorisk orienterede kritik. Makkerparret Harly Sonne og Christian Grambyes psykosemiotiske bidrag (der passende er placeret som nummer tre i rækkefølgen) bygger $\mathrm{i}$ navn og gerning bro mellem disse etablerede, hvis ikke toneangivende traditioner og senere poststrukturalistiske udviklinger, repræsenteret af henholdsvis postfeministen Charlotte Engberg og dekonstruktivisten Jan Rosiek. Fortolkningseksperimentets pædagogiske og videnskabelige fordele er måske særligt oplagte i de tilfælde, hvor kontinuiteten mellem teori og praksis ikke formidles af en metodisk systematik, og hvor man evt. som Jan Rosiek insisterer på tekstteoriens eksistensberettigelse uafhængigt af dens mulige værdi for den konkrete analyse. Bogens prioritering er den modsatte - som det også fremgår af titlen. Så uanset om de enkelte resultater af deltagemes dialog med Jakobsens novelle fremlægges som besvarelsen af et sæt programmatiske spørgsmål til teks- 
ten eller som et forslag til, hvorledes en typisk poststrukturalistisk »læsning《 kunne tage sig ud, vurderes præstationerne i relation til en af dem alle anerkendt norm, der definerer den gode fortolkning som en præcist karakteriserende beskrivelse af den individuelle tekst. Suiten af bidrag følges op af en rundbordsamtale, hvor forfatterne elskværdigt udæsker hinanden, veloplagt styret og sekunderet af redaktøren Anders Østergaard. Sidstnævnte er i $\varnothing$ vrigt mester for indledningen, der fortjener at fremhæves som en yderst informativ og overbliksgivende introduktion til de sidste fyrre ărs danske kritikhistorie og til litteraturvidenskabens receptionsteoretiske grundlagsproblemer.

Nogle læsere vil nok finde, konstaterer redaktøren lidt undskyldende, at en fuldblods nykritiker glimrer ved sit fravær. Man savner ikke dette rene væsen. Dels fordi, som det også bemærkes, nykritikkens krav om æstetisk følsomhed er gået de sidste generationers kritikere $\mathrm{i}$ blodet som en dybest set uanfægtet arv. Dels fordi dens litteraturbegreb stadig synes at gøre sin indflydelse teoretisk og normativt gældende. Dette er ikke mindst tydeligt hos Søren Schou, der under sin ræsonnable metoderefleksion, som fastholder den bevaringsværdige distinktion mellem en symptomal og en intentional anskuelsesmåde, gør store indrømmelser til nykritikkens autonomidoktrin: Først diagnosticeringen af novellens »mærkværdigheder $\ll$, patologiske ejendommeligheder ved hovedpersonen Henning, som fortælleren ikke markerer kritisk distance til, legitimerer overvejelser over tekstens psykobiografiske produktionsbetingelser. Halvfjerdsernes socialhistoriske kritiker ville ikke have vist nogen betankeligheder ved en lignende taktløshed og utvivlsomt forkaste Søren Schous revision som utilladeligt revisionistisk. Han indskrænker nemlig den repræsenterede tilgangs teoretiske forudsatninger til en aksiomatisk forventning om, at enhver tekst eksisterer $i$ et ikke tilfældigt forhold til sine historiske omgivelser. Hermed ryger for det første astetiske kvalitetskriterier, ifølge hvilke litterære tekster bør afspejle samfundstotaliteten. For det andet bestræbelsen på at integrere kontekstualiseringen i temaanalysen ved hjælp af særlige oversættelses - og slutningsregler, der engang har lugtet til empiri. Søren Shcou praktiserer en mere »udvendig « genetisk relatering af tekstens ubevidste konfliktstof $o g$ afstår fra at afkode den overordnede modsætning på det intentionelle niveau som en tilsl $\varnothing$ rende representation af klasseantagonismen. Novellens tema bestemmes som et naturalistisk opgør med en idealistiskromantisk livsanskuelse, der foreligger i kraft af overlagte motiviske referencer til Webers opera »Jægerbruden «. Opfattelsen af idé - og litteraturhistorie som fuldgyldige aspekter af socialhistorien, danner baggrund for hans udforskning af sammenstødet mellem de to »tekstrum «. Sagt en passant bevidner Skud, at agtpågivenhed over for fænomenet intertekstualitet gennemgående afstedkommer de mest frugtbare iagttagelser, når den pågældende relation ytrer sig som tekstens (polemiske) dialog med en anden bestemt tekst. Det fremgår positivt af den måde, Søren Schou, Erik A. Nielsen og Jan Rosiek udnytter deres for de to førstes vedkommende identiske - opdagelser på.

Indehaveren af den social-historiske »karaktermaske« finder novellens gestaltning af brydningerne mellem kapi- 
talisme og feudalisme så (nationalt) uspecificerede, at der ikke er grund til at beskaftige sig yderligere med den. Det er ham muligvis magtpåliggende som et skyldigt hensyn til værkautonomien at profilere tekstens unikke specifitet. De kasserede relevanskriterier samles til gengæld op af Sonne og Grambye. $\gg$ Tekstanalysen «, som ophavet med ubeskeden, men saglig konsekvens benævner deres metodelære, er en konstruktion med mange boliger, hvor marxistiske synsmåder $\mathrm{i}$ relativ ubemærkethed får lov til at give deres besyv med: Således burde Hennings handelskapitalistiske succes i princippet have ført til frigørelse fra en forældet produktionsforms værdier. Men stærkere krafter vil det anderledes, og det er dem , der tages under behandling i psykosemiotikkens mest spektakulære indsats: diegesemodellen, det geometiske udtryk for sammentænkningen af strukturalistisk narratologi og lacaniansk psykoanalyse. Diegesemodellen hævdes at befordre indsigt $\mathrm{i}$ både tekstinterne og receptionspsykologiske forhold. Gennem sin identifikatoriske tilegnelse af den narrative tekst, hvis hovedperson dramatiserer kritiske overgange i subjektets psykosexuelle individuationsproces, vil en opslugt fiktionslæser bringes i stand til på den indre scene at gennemløbe sin egen ontogenese endnu en gang. Tilsvarende kan måske tekstanalytikeren ses at rekapitulere hovedpunkterne i sit teoretiske dannelsescurriculum, når modellen anvendes korrekt. Det ville være kongenialt med psykosemiotikkens på nogle punkter scientistiske selvforståelse. Sonne og Grambye, der afparerer bravt, må høre en del for deres $\gg$ isenkram «, katastrofiske kastrationer og fremmedord. De kan have ret $i$, at den $\varnothing$ dipale for- ventningshorisont er langt mindre indsnævrende end så meget andet, der kalder sig forudsætningsløst. Men deres honorering af det videnskabelige (og pædagogiske) krav om systematisk udtømmende tekstbeskrivelse synes at føre til en - hvad angår underholdningsværdi - noget nivellerende fremstilling. Man forbigår intet signifikant, men afskærer sig tendentielt fra en selektiv fordybelse i den karakteristiske detalje. Som Erik A. Nielsen, der lader sig lede af intuitionens punktnedslag, modsætningsvis favoriserer. Man glemmer sent hans fascinerende udlægning af Hennings dræbende skud i tågen som et $»$ studie i patologiens monomane præcisionsfokusering «. Det foreliggende afkast af »tekstanalysen« kan foresvæve læseren som som en særdeles velskrevet og i sine pointer uangribelig, men alligevel ikke ganske passende formidling af det $s æ-$ regne ved novellen: Den strammer ikke alarmerende nogen steder og den dækker det hele - omtrent som en flyverdragt, der er k $\varnothing b t$ til at vokse i. De mest prægnante indsigter falder $i$ forbindelse med udsigelsesanalysen, der rummer ansatser til en udkrængende og begrebsligt præcis definition af »horror «- genren, som i $\varnothing$ vrigt flertallet af deltagerne læser Jakobsens novelle ind i. Her viser den psykosemiotiske »sonde «sig at være nok så erkendelsespotent som mangen anelsesfuldt svejende tentakel.

Spørgsmålet om litteraturens mulighed for at overskride sine givne betingelser synes fortrinsvis at engagere den ældre generation, der for så vidt vedkender sig en af Charlotte Engberg tilsyneladende afskrevet emancipationshumanisme. Det er på denne baggrund at de angriber hinandens »metaforer «: Erik A. Nielsen den psykosemiotiske $» k o n-$ 
struktion « for at konnotere noget mekanisk og tingsligt. Disse betydninger forsvares ikke desto mindre som en medreflektering af betydningsproduktionens symbolske naturtrancendens, der på godt og ondt betinger den menneskelige frihed.. Erik A. Nielsens »organiske« begribelse af værket har derimod til hensigt at formidle anskuelsen af den $æ$ stetiske kreativitet som en livsproces, der også hævdes at stræbe mod forklarelse og selvbevidsthed. Søren Schous forundring gælder især tekstens syntetisering af heterogene eller ligefrem modstridende motivationer, af overjegets »bevidste《 intentioner og den »ubevidste« id-determination. Men »hvem« eller hvad bringer denne koordinering $\mathrm{i}$ stand? Er det Erik A. Nielsens »formkræfter«, der romantisk suggererer forstillingen om en målrettethed, der ikke kontrolleres af, men nok konvergerer med producentens vilkårlige styringer? Eller er det jeg'et; og antydes det, at den marginaliserede ego-psykologi kunne tænkes at kaste lys over denne procesorienterede problemstilling? Det ville $\mathrm{i}$ hvert fald ikke være nogen dårlig idé.

En problemstilling er jo er snævert forbundet med spørgsmålet om, hvad man skal forstå ved tekstens intentioner, og som også drøftes. Med erklæringen om, at »strukturel intentionalitet er en contradictio in adjecto «, afviser Søren Schou den poststrukturalistiske tendens til at negligere tekstens status som et udtryk for en individuel subjektivitet. Jan Rosiek, der generelt tøver med at tilslutte sig dekonstruktionens mest radikale synspunkter, modstiller i sin analyse »fortællerens hensigter og »tekstens indsigter $\ll$. Han tager her ikke utvetydigt stilling til, om teksten overskuer eller er uvidende om den opposition, indsigten er en del af. Således bliver det vanskeligt at afgøre, i hvilken udstrækning analysen har taget teoriens omstødelse af den integrerende udsigelsesinstans, altså af den »implicitte fortæller« som tekstens »overordnede bevidsthed « til praktisk efterretning. Forfatteren vedgår, at spørgsmålet om tekstens brudthed eller delthed egentlig ikke interesserer ham, og man har fornemmelsen af, at det primært er med henblik på nykritikkens forkærlighed for tematiske forsoninger, at han distancerer sig fra dens modsætningsbegreb. Med så meget desto større ret fremhæver han dekonstruktionen som nykritikkens kritiske arvtager. Under alle omstændigheder kan insisteringen på tekstens binære struktur ses at indebære en - om muligt: ufrivillig - bekendelse til »helheden «. At være kløvet af en indre modsigelse er nu engang ikke den ringeste måde at hænge sammen på. Jan Rosiek mener i øvrigt, at dekonstruktionen med tropologien har gjort nykritikkens nærlæsning »endnu mere nær«. Om det virkelig forholder sig sådan afhænger vel i høj grad af, om man stadig accepterer, at tekstens materiale, hvortil også hører retorikkens forskellige tekniske principper for poetisk billeddannelse, først tildeles en semantisk funktion som følge af integrationen $i$ enkeltværkets differentielle betydningsdannelse. At f. eks. den allegoriske repræsentation an sich skulle artikulere en bevidsthed om det uoverstigelige svælg mellem virkelighed og sprog er en tankevækkende hypotese, der imidlertid ikke sjældent fører sig noget dogmatisk frem. Med god grund. For her kan det ene postulat give det andet end håndsrækning: Hvis teksten mener ja , når den siger nej - og for det meste også, når 
den siger ja - er det alt andet lige muligt at verificere hvad som helst.

Jan Rosiek er dog selv en yderst samvittighedsfuld nærlæser. Hans sprogteoretiske fortolkning, der viser os Henning som ansporet af et »bogstavelighedens projekt «-- bestandig truet af den subversive »metafor $\ll-$ afprøves i forhold til forløbets kausale og psykologiske begrundelsessammenhæng. Man kunne med mindre intellektuel redelighed have klaret sig med en påstand om, at hovedpersonens bestræbelse på med pengenes magt at beherske og triumfere over sine omgivelser, herunder kusine Agathe, dybest set var ækvivalent med en særlig fallogocentrisk sprogholdning. For analysens Henning - i să henseende noget af en klassisk idealistisk dannelseshelt er sproglighedens eksistentielle vilkår som sådan et seriøst personligt engagement, der overskygger mere banale egoistiske tilskyndelser. Ejendommeligheder ved dekonstruktionens undertiden depræciserende jargon bliver ikke desto mindre drastisk udslagsgivende for bestemmelsen af fortællerens hensigter som gående ud på at »patologisere metaforen«. Alle former for imaginær aktivitet stimler forskelsløst sammen under betegnelsen "metafor «. Så der ikke skelnes mellem delirium og digt. Respekterede man normalt anerkendte begrebsadskillelser kunne historien uden videre aftvinges en stik modsat morale, hvor indsigt så at sige gør sig til hensigt: Fordi den analogiske fantasifunktion fornægtes i sin egenskab af »metaforisk « uigennenskuelighed, rollespil, æstetisk illusion m.m., må den vende frygteligt tilbage som psykose. Intet tyder i øvrigt på, at den subtilt nøjeregnende Rosieks egne sekundærprocesser skulle have taget skade som følge af o- verdreven indlevelse i fiktionens Henning. Så den umådeholdne »metaforisering af metaforen « - som Anders Østergaard formulerer det - skyldes nok hans ønske om med sin analyse at indfri forventningerne om den »rene vare «. Jan Rosiek og Charlotte Engberg er som de selv påpeger - anbragt på noget af en Uriaspost. I begge tilfælde tages udfordringen skarpsindigt og opfindsomt op. Det er alt i alt udbytterig læsning, ikke mindst for den, der gerne vil stifte bekendtskab med noget så profant som et konkret eksempel på det post og nymodens, der kan kommunikere.

Postfeministen Charlotte Engberg fokuserer i sin fortolkning af novellen på (bi)figuren Agathe som den dæmoniske femme fatale, projektionen af mandens begær efter at løse kønnets gåde. Hun understreger selv, at novellens eneste kvindelige akt $\varnothing \mathrm{r}$ indtil sin postmortale tilsynekomst som strangulerende hævnånd, ikke opfører sig synderligt ukonventionelt. Hertil kan føjes, at Agathes dæmoniske destruktivitet ved denne lejlighed er tilfredsstillende begrundet $\mathbf{i}$ den uret, hun har lidt, samt at hun fra fortællerens side ikke tilskrives nogen fatal udstråling. Disse og andre mulige indvendinger har fortolkeren på forhånd måttet sætte sig ud over. Figurens fatalitet fremstår $i$ hendes optik mindre som et dramatisk moment $i$ den narrative struktur end som dennes usynlige konstitutionspunkt. Charlotte Engberg argumenterer mindre cirkulært i sin redeg $\varnothing-$ relse for novellens billedplan og sandsynliggør med forfølgelsen af farvesymbolikkens progressive udfoldelse sin postfeministiske opfattelse af teksten.

Præfixet »post-« forklarer muligvis analysens bemærkelsesværdige sløring af udsigelsesforholdene, hvad angår 
Hennings, fortællerens, tekstens og forfatterens respektive andel i kønnets forblændelser. Men for at kunne kvalificere sig til resten af prædikatet må den vel bestride gyldigheden af de kulturelt verserende og tidstypiske fantasier, teksten ses at formidle, som udtryk for hvad mænd har behov for at bilde sig ind. Også selv om det fremhæves, at ingen heller ikke kvinder - længere har patent på sandheden. Positionens erklærede afstandtagen fra den tidligere feministiske ideologikritik ytrer sig måske ikke mindst i Charlotte Engbergs sprog, der er velgørende frit for moraliserende overtoner.

Den neddæmpede retorik er konsistent med hendes ubehag ved i sin egenskab af fortolker at indstifte et beherskelsesforhold mellem sig selv og den æstetiske tekst. Fortolkningssituationens dilemma skitseres: Blot at gentage tekstens mening ville være et meningsløst hermaneutisk forehavende, men rummer alternativet ikke altid allerede en risiko for anmasselse? Hun udtaler dog forhăbningsfuldt, at man måske kan vide noget andet uden dermed at vide bedre. Men er det ikke en tvivlsom distinktion? Når man stryger teksten mod hårene er det formentlig $\mathrm{i}$ forventning om at afdække betydninger, som den »selv« har overset. Også når sidstnævnte skønnes mere fængslende end »grovkornet psykologi« »trivialsymbolik « eller andre angivelige ubehjælpsomheder, som først bliver æstetisk interessante ved at indgå $i$ en brudfyldt komposition, Og i det omfang Charlotte Engbergs analyse rummer en symptomal dimension, ved hun $\mathrm{i}$ hvert fald mere end teksten.
Den poststrukturalistiske kritikers skrupuløse selvrefleksion synes fortrinsvis at forstå det intellektuelle hovmod som et spørgsmål om hvilken type af sproghandling, man kaster sig ud i. Men i praksis afhænger meget vel også af ens personlige åbenhed i relation til teksten - og til de ligeledes bedrevidende forskningsfæller. Hvor afgørende tonen har ændret sig i begge henseender er Skud selv et klart vidnesbyrd om . De tider synes at være uigenkaldeligt forbi, hvor kritikeren kendte remediet mod den pletskaldede mangel på indre sammenhæng, der afsløredes under harmoniseringernes hentehår. Og som endelig Jan Rosiek afdramatiserende sammenfatter: »Vi har jo heldigvis ikke liv i vores hænder, når vi læser teksten«. I lighed med andre reproducerbare åndsprodukter og til forskel fra andre organismer, kan litterære tekster ikke gå i stykker og tåler følgelig alle former for ublid manipulation. Det eneste de ikke overlever, er som bekendt fortielse. Den fare synes ikke at være overhængende for J. P. Jacobsens novelle, der takket være en ved sine laservenlige analyser, dybsindige diskussioner og sin perspektivrigdom usædvanligt stimulerende bog foreløbig kan se receptionshistoriens fremtid imøde med fortrøstning. 